\title{
Borage (Borago officinalis L.) response to salinity at early growth stages as influenced by seed pre-treatment
}

\author{
Faride Feghhenabi ${ }^{\text {a }}$, Hashem Hadi ${ }^{a}$, Habib Khodaverdiloo ${ }^{\text {b, }}$, Martinus Th. van Genuchten ${ }^{\text {c,d }}$ \\ ${ }^{\text {a }}$ Department of Plant Production and Genetics, Urmia University, Urmia, Iran \\ ${ }^{\mathrm{b}}$ Department of Soil Science, Urmia University, Urmia, Iran \\ ${ }^{c}$ Department of Earth Sciences, Utrecht University, Utrecht, the Netherlands \\ ${ }^{\mathrm{d}}$ Center for Environmental Studies, CEA, São Paulo State University, UNESP, Rio Claro, SP, Brazil
}

\section{A R T I C L E I N F O}

Handling Editor: Dr. B.E. Clothier

\section{Keywords:}

Germination

Emergence

Seed pre-treatment

Salt-affected soils

Salinity crop response functions

\begin{abstract}
A B S T R A C T
Knowledge of plant response to salinity, especially at early growth stages, is critical to optimizing crop production in salt-affected soils. In this paper we explore quantitatively the effectiveness of seed pre-treatment to lessen the effects of salinity on Borage (Borago officinalis L.) seed germination and subsequent seedling growth. Two independent experiments were conducted with nine salinity levels and five seed pre-treatments using Lake Urmia saline water (LUsw), ascorbic acid (Asc), proline (Pro), potassium silicate $\left(\mathrm{K}_{2} \mathrm{SiO}_{3}\right)$ and spermidine (Spd). The first set of experiments was used to obtain the most effective pre-treatments for seed germination. The second set of experiments investigated the combined effects of salinity and seed pre-treatment concentration on the emergence process. Salinity was found to have considerable inhibitory effects on seedling growth, but pretreating the seeds alleviated some of these effects. Seedling response to salinity could be described well using the threshold-slope salinity response function of Maas and Hoffman (1977) and the S-shaped function of van Genuchten and Hoffman (1984). A means comparison (using Tukey's test) showed that the mean salinity threshold of all seedling traits, $E C^{*}$, increased markedly $(P \leq 0.001)$. For example, $E C^{*}$ increased $60 \%$ using $\mathrm{K}_{2} \mathrm{SiO}_{3}$ as compared to the control, with Spd and Pro having less of an effect on on $E C^{*}$ than $\mathrm{K}_{2} \mathrm{SiO}_{3}$. The mean $E C$ value at which various seedling traits were reduced by $50 \%$ (i.e., $E C_{50}$ ) increased from $10.8 \mathrm{dS} \mathrm{m} \mathrm{m}^{-1}$ for the control to $12.5,12.5$ and $12.1 \mathrm{dS} \mathrm{m}^{-1}$ for the Pro, $\mathrm{K}_{2} \mathrm{SiO}_{3}$ and Spd pre-treatments, respectively. Statistically, the effects of Pro, $\mathrm{K}_{2} \mathrm{SiO}_{3}$, Spd on $E C_{50}$ were essentially the same. The effects of Asc, and LUsw on $E C_{50}$ were not significant compared to the control. The increased vigor of seedlings obtained by seed pre-treatment, particularly when using $\mathrm{K}_{2} \mathrm{SiO}_{3}$, should lead to more salt-tolerant plants and higher yield potentials in saline environments.
\end{abstract}

\section{Introduction}

Soil salinization is a major problem limiting agricultural productivity in many regions of the world. While salt-affected soils occur in all climatic areas, and at a wide range of altitudes, they are most frequent in arid and semiarid regions. For example, about $7 \%$ of the world's and $55 \%$ of Iran's agricultural land is affected by salinity, with the impacts of salinity expected to increase in the near future (Bagheri et al., 2015; Kafi and Rahimi, 2011). Salinity is one of the most important abiotic stresses causing reductions in agricultural productivity (Uddin and Juraimi, 2013; Wei et al., 2015). Salinity induces such primary effects as osmotic and ionic stress, as well as indirectly secondary effects involving oxidative stress on plants (Li et al., 2008).
The capability of plants to endure and sustain growth in saline environments (i.e., plant salt tolerance) is vital for the ecological spreading of plant species and their cultivation in arid, semiarid, and salinityaffected areas. Salt tolerance is an adjustable trait related to many factors, including especially plant species (Munns and Tester, 2008). Investigations on plant tolerance to salinity stress have involved a range of molecular, physiological and morphological factors. Due to increasing salinity problems worldwide, improved field-scale irrigation and salinity management practices (Skaggs et al., 2006), as well as development of more salt tolerant plants (Patade et al., 2009) should be major priorities.

Salinity tolerance during the germination and emergence stages is a major indication of salt tolerance at later growth stages (Kutlu et al., 2009). Identifying or possibly enhancing crop salt tolerance prior to

\footnotetext{
* Corresponding author.

E-mail address: h.khodaverdiloo@urmia.ac.ir (H. Khodaverdiloo).
} 
sowing is hence vital. Seed pre-treatment or seed priming is a pre-planting practice that involves the exposure of seeds to limited hydration using external low-water potentials. Seed pre-treatment has been shown to enhance germination and emergence under saline conditions for a variety of crops (Aloui et al., 2014; Demir Kaya et al., 2006; Patanè et al., 2009; Pill et al., 1991; Sadeghi and Robati, 2015). Chomontowski et al. (2020) concluded that the efficiency of seed pre-treatment is higher in seeds with lower vigor than those with higher vigor. Since poor seed germination is a major reason limiting the large-scale cultivation and production of medicinal plants under saline conditions, seed pre-treatment may well become very attractive. Several factors affecting the response of seeds to pre-treatment indicate that suitable material with precise concentrations used for seed pre-treatment will improve seed germination under water and salinity stress conditions (Kazemi and Eskandari, 2012). The effects of different seed pre-treatments, as an agricultural technique, could explored also from an ecophysiological point of view. In ecophysiology, the mechanistic understanding of a plant community in response to seed pre-treatments and salinity can be improved by focusing on such issues as physiology, biochemistry, biophysics, and molecular biology.

Many compounds have been used for seed pre-treatment. Proline as an organic osmolyte, in addition to osmotic protection, has been shown to be a key factor to reduce the harmful effects of salinity, and to accelerate post-stress recovery through detoxification of reactive oxygen species (ROS), protection of membrane integrity, and stabilization of proteins/enzymes from stress (Shakirova et al., 2003). Shafiq et al. (2018) concluded that seed pre-treatment with proline mediated improvements in growth and antioxidant enzyme activities contributed to stress tolerance, which partly relied on the ability of plants to absorb sodium and partition it in wheat roots. As a beneficial plant nutrient, silicon (Si) is known to play a crucial role in regulating and alleviating many biotic and abiotic stresses, including from drought, salt and heavy metals, through enhanced membrane stability, production of antioxidants and photosynthetic efficiency, and reductions in oxidative damage. As a seed pre-treatment, application of $1.5 \% \mathrm{Si}$ under water stress conditions improved biological yield and grain yield of wheat (Mukhtar et al., 2015). Ascorbic acid (Asc), an abundant relatively small molecule in plants, further has been shown to play multiple roles in plant growth. For example, Ajmal Khan et al. (2006) found that Asc as seed pre-treatment can improve germination by scavenging undue superoxide radicals or singlet oxygen. Spermidine (Spd) is a ubiquitous low-molecular-weight aliphatic amine involved in various biochemical and physiological processes related to the regulation of plant growth and development. Seed pre-treatment with Spd improved seed germination under different water stress conditions. Improvements in the metabolism of starch was suggested as a probable cause for this seed invigoration (Li et al., 2014). Halo-priming or seed pre-treatment with salt solutions such as $\mathrm{KCl}$ and $\mathrm{CaCl}_{2}$ is another method to improve tolerance against salinity stress. Islam et al. (2015) reported that low proline and $\mathrm{Na}^{+}$contents caused enhanced salt tolerance of halo-primed wheat. Still, the response to salinity at any growth stage differs among species, and even among cultivars (Bojovi et al., 2010).

Plant survival during germination is one of the most important salinity tolerance indices, while subsequent yield and growth reductions are criteria for the ultimate salinity tolerance of plants as discussed by Saadat and Homaee (2015). Models of whole-plant response to environmental stresses can be useful for comparing the degree of salinity tolerance of different species, including their application to practical field problems (Maas and Hoffman, 1977; Skaggs et al., 2006; Steppuhn et al., 2005). Functional descriptions of seed germination and emergence can similarly be effective to quantify seedling emergence and subsequent plant response to salinity. Several salinity-dependent reduction functions (Maas and Hoffman, 1977; van Genuchten and Hoffman, 1984) have been used over the years to quantify whole-plant response to salinity stress. To our best knowledge, very few studies (e.g., Feghhenabi et al., 2020) have used these functions to assess the effects of seed pre-treatment on the response of plants to salinity in a quantitative way.

Borage (Borago officinalis L.) is a valuable annual medicinal herb suitable for cultivation in many countries, including Iran (Chakovari et al., 2016; Naghdi Badi and Sorooshzadeh, 2011). High salt tolerance and absorption of minerals by this plant have been mentioned in several studies (e.g., Asadi-Samani et al., 2014; Ghassemi-golezani et al., 2013; Torabi et al., 2012). However, these studies did not include a quantitative response of Borage to increasing salinity levels such as salinity threshold values. Therefore, in addition to a quantitative assessment of Borage response to salinity at early growth stages, our study determines how seed pre-treatment affects Borage response to salinity after germination. Specific objectives were to $i$ ) determine the tolerance of Borage to salinity stress with or without different seed pre-treatments, ii) explore the quantitative response of Borage to salinity with or without the various seed pre-treatments and, consequently, iii) select the most effective seed pre-treatments for moderating the effects of salinity, including the best function for describing Borage response to salinity at the seedling stage.

\section{Materials and methods}

Our study was conducted in 2017 at the Seed Technology Laboratory of the Faculty of Agriculture and Natural Resources of Urmia University (Urmia, Iran). Borage seeds were provided by PAKAN BAZR Company (Esfahan, Iran). Fig. 1 shows a flowchart of the various experiments that were conducted. The pre-experiments showed a mean 100-seed weight of $2.03 \mathrm{~g}$, while seed moisture contents ranged between $5 \%$ and $6 \%$. Borage seeds showed a $100 \%$ germination percentage at $25{ }^{\circ} \mathrm{C}$ as assessed using Petri dishes. The seeds further were surface-sterilized in a $1 \%$ sodium hypochlorite solution, rinsed with distilled water, and dried prior to the Phase- 1 and Phase-2 experiments.

The main experiments involved two consecutive steps. Phase- 1 experiments were used to estimate the final germination rate $(G R)$ of seeds and the germination percentage (GP). This produced initial data about the response of seed germination to different concentrations of various seed pre-treatment agents at the applied salinity levels. The most effective concentration of each seed pre-treatment was then selected for the next step. The Phase- 1 experiments hence were used to compare control (untreated) seeds and pre-treated seeds. For the pre-treatment experiments we placed subsamples of the seeds into 100-ml flasks. Table 1 shows the type, concentration and duration of the seed pretreatments. A zero concentration was considered as the control. The seed pre-treatments and their concentrations were selected based on many previous studies (Ghassemi-golezani et al., 2013; Ibrahim, 2016; Kadkhodaie and Bagheri, 2012; Kazemi and Eskandari, 2012; Mukhtar et al., 2015; Sivritepe et al., 2003; Torabi et al., 2012). After pre-treatment, the seeds were thoroughly rinsed consecutively with tap and distilled water, dried with blotting paper and then left overnight at room temperature. After drying, the moisture contents of the treated seeds were found to be similar to those of the untreated seeds. After being surface-sterilized in a sodium hypochlorite solution, the seeds were used for the experiments $36 \mathrm{~h}$ after the pre-treatments.

Saline solutions $\left(0,2,4,6,8,10,12,14\right.$ and $\left.20 \mathrm{dS} \mathrm{m}^{-1}\right)$ were prepared using the saline water of Lake Urmia and distilled water depending upon target salinity levels. The salinity of each solution was measured using an electrical conductivity meter (EC meter), with results expressed in $\mathrm{dS} \mathrm{m} \mathrm{m}^{-1}$ at $25{ }^{\circ} \mathrm{C}$. Phase- 1 experiments were carried out following a completely randomized design with four replicates. Each replicate involved 100 primed seeds placed in covered Petri dishes containing a single filter paper moistened with $7 \mathrm{ml}$ of each saline water solution. The Petri dishes were placed in a germinator at $25 \pm 2{ }^{\circ} \mathrm{C}$ in the dark. Data were collected every $12 \mathrm{~h}$ until no further germination occurred for $48 \mathrm{~h}$. At the end of the Phase- 1 experiments, estimates of the final $G P$ and $G R$ values were obtained using methods described by Babakhanzade Sajirani et al. (2011). The results were used to select the 


\section{Pre-experiments}

Pre-testing the seeds (measuring 100-seed weights, seed moisture contents, testing germination percentages, surface-sterilizing the seeds)

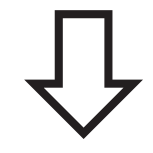

\section{Phase-1 Experiments}

Testing seed germination rates $(G R)$ and germination percentages $(G P)$ using different seed pre-treatment concentrations ${ }^{\#}$ :

$\left\{\begin{array}{l}\text { 1. Control } \\ \text { 2. Asc at } 0,50,75,100 \mathrm{mM} \\ \text { 3. Pro at } 0,12,17,20 \mathrm{mM} \\ \text { 4. } \mathrm{K}_{2} \mathrm{SiO}_{3} \text { at } 0,1,1.5,2 \mathrm{mM} \\ \text { 5. Spd at } 0,0.5,1,1.5 \mathrm{mM} \\ \text { 6. LUsw at } 0,100,150,200 \mathrm{mg} \mathrm{L}^{-1}\end{array}\right.$

at salinity levels of $0,2,4,6,8,10,12,14$ and $20 \mathrm{dS} \mathrm{m}^{-1}$

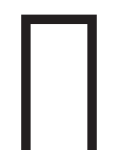

Selecting the optimal pre-treatment concentration:

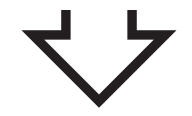

1. Control

2. Asc at $75 \mathrm{mM}$

3. Pro at $12 \mathrm{mM}$

4. $\mathrm{K}_{2} \mathrm{SiO}_{3}$ at $1.5 \mathrm{mM}$

5. Spd at $1.5 \mathrm{mM}$

6. LUsw at $150 \mathrm{mg} \mathrm{L}^{-1}$

\section{Phase-2 Experiments}

Evaluating the effects of salinity on seedling development in greenhouse conditions by estimating:

i) the final maximum emergence percentage $\left(E_{\max }\right)$,

ii) the rate at which the seedlings reach $50 \%$ emergence $\left(R_{50}\right)$,

iii) the vitality index $(V I)$,

iv) the reciprocal of the emergence uniformity (REU)

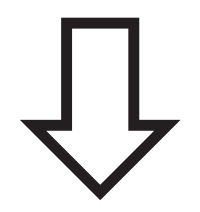

\section{Modeling Phase}

Describing the effects of seed pre-treatment and salinity on plant growth using salinity response functions.

Fig. 1. Flowchart of the study (Asc, ascorbic acid; Pro, proline; $\mathrm{K}_{2} \mathrm{SiO}_{3}$, potassium silicate; Spd, spermidine; LUsw, Lake Urmia saline water). 
Table 1

Treatments at the germination and emergence stages.

\begin{tabular}{|c|c|c|c|c|}
\hline $\begin{array}{l}\text { Growth } \\
\text { stage }\end{array}$ & $\begin{array}{l}\text { Seed pre- } \\
\text { treatments }^{\#}\end{array}$ & $\begin{array}{l}\text { Seed pre- } \\
\text { treatment } \\
\text { concentrations }\end{array}$ & $\begin{array}{l}\text { Duration of } \\
\text { seed pre- } \\
\text { treatment }\end{array}$ & $\begin{array}{l}\text { Salinity levels } \\
\text { for all } \\
\text { treatments (dS } \\
\mathrm{m}^{-1} \text { ) }\end{array}$ \\
\hline \multirow[t]{6}{*}{ Germination } & Control & - & - & \multirow{6}{*}{$\begin{array}{l}0,2,4,6,8, \\
10,12,14,20\end{array}$} \\
\hline & Asc & $\begin{array}{l}0,50,75 \\
100 \mathrm{mM}\end{array}$ & $24 \mathrm{~h}$ & \\
\hline & Pro & $0,12,17,20 \mathrm{mM}$ & 2 days & \\
\hline & $\mathrm{K}_{2} \mathrm{SiO}_{3}$ & $0,1,1.5,2 \mathrm{mM}$ & $6 \mathrm{~h}$ & \\
\hline & Spd & $0,0.5,1,1.5 \mathrm{mM}$ & $10 \mathrm{~h}$ & \\
\hline & LUsw & $\begin{array}{l}0,100,150 \\
200 \mathrm{mg} \mathrm{L}^{-1}\end{array}$ & $10 \mathrm{~h}$ & \\
\hline \multirow[t]{6}{*}{ Emergence } & Control & - & - & \multirow{6}{*}{$\begin{array}{l}0,2,4,6,8, \\
10,12,14,20\end{array}$} \\
\hline & Asc & $75 \mathrm{Mm}$ & $24 \mathrm{~h}$ & \\
\hline & Pro & $12 \mathrm{mM}$ & 2 days & \\
\hline & $\mathrm{K}_{2} \mathrm{SiO}_{3}$ & $1.5 \mathrm{mM}$ & $6 \mathrm{~h}$ & \\
\hline & Spd & $1.5 \mathrm{mM}$ & $10 \mathrm{~h}$ & \\
\hline & LUsw & $150 \mathrm{mg} \mathrm{L}^{-1}$ & $10 \mathrm{~h}$ & \\
\hline
\end{tabular}

${ }^{\#}$ Asc, ascorbic acid; Pro, proline; $\mathrm{K}_{2} \mathrm{SiO}_{3}$, potassium silicate; $\mathrm{Spd}$, spermidine; LUsw, Lake Urmia saline water.

most effective concentration for each treatment, further referred to as the optimal pre-treatment concentration. The reduction slope (the decline in germination or another trait per unit increase in salinity) and the y-intercept of the regression line obtained from these results was subjected to an analysis of variance. Means comparison Tukey-HSD tests were performed next, with the level of significance at $<0.05$. A mild slope reflects greater sustainability of a particular trait in response to increased salinity levels. Therefore, the concentration that was most effective to increase seedling resistance to salinity (i.e., by reducing the slope) should be used in further evaluations (KhoshKholg Sima et al., 2014; Maggio et al., 2004; Steppuhn et al., 2005). Still, one must also consider the importance of y-intercept.

The Phase- 2 experiments were used to examine, for each optimal pre-treatment, the effects of salinity on subsequent seedling growth during a period of 14 days. The experiments for this purpose were conducted in a greenhouse with a $12 \pm 1 \mathrm{~h}$ photoperiod at $22.5 \pm 2.5{ }^{\circ} \mathrm{C}$, a $50 \pm 10 \%$ relative humidity (day/night), and a light intensity of $700 \mu \mathrm{mol} \mathrm{m} \mathrm{m}^{-2} \mathrm{~s}^{-1}$. Ten germinated seeds were planted at a depth of $2 \mathrm{~cm}$ in PVC pots $(16 \mathrm{~cm}$ high and $7 \mathrm{~cm}$ in diameter and filled with local farm soil). The seedling density per pot was reduced to four after emergence. The loam soil used for the experiments (sand, silt and clay percentages were $46 \%, 33 \%$ and $21 \%$, respectively) was non-saline (the electrical conductivity of the saturation paste was $1.1 \mathrm{dS} \mathrm{m}^{-1}$ ), contained $18.5 \%$ equivalent $\mathrm{CaCO}_{3}$, and had a $\mathrm{pH}$ value of 7.7 .

The experiments produced estimates of the final maximum emergence percentage $\left(E_{\max }\right)$, the rate at which the seedlings reached $50 \%$ emergence $\left(R_{50}=1 / D_{50}\right)$, the vitality index (VI, being the length of the seedlings $\times E_{\max }$ ), and the reciprocal of the emergence uniformity $\left(R E U=1 / E U\right.$, where $\left.E U=D_{90}-D_{10}\right) . D_{10}, D_{50}$ and $D_{90}$ represent the numbers of days needed to reach $10 \%, 50 \%$ and $90 \%$ of emergence, respectively. When the difference between $D_{10}$ to $D_{90}$ increases, the emergence uniformity $(E U)$ decreases and $R E U$ increases. Seedling development rates were evaluated by measuring a range of seedling root and stem attributes, including lengths and dry weights, 16 days after planting.

The effects of seed pre-treatment and salinity on the various traits were evaluated in terms of several salinity stress response functions. Historically the most popular response function has been the linear threshold-slope model by Maas and Hoffman (1977), given by

$\alpha(E C)= \begin{cases}1 & 0 \leq E C<E C^{*} \\ 1-b\left(E C-E C^{*}\right) & E C * \leq E C<E C *+1 / b) \\ 0 & E C \geq E C *+1 / b\end{cases}$

where $\alpha$ is the specific trait being considered in relative terms
$(0 \leq \alpha \leq 1)$ as a function of soil salinity, $E C\left(\mathrm{dS} \mathrm{m}^{-1}\right) ; E C^{*}$ is the salinity threshold value, and $b$ is the slope of the response function. Since experiments often do not show the linear response to salinity typical of Eq. (1), van Genuchten and Hoffman (1984) proposed an alternative S-shaped response function of the form:

$\alpha(E C)=\frac{1}{1+\left(E C / E C_{50}\right)^{p}}$

in which $E C_{50}$ is the soil salinity at which $\alpha$ is reduced by $50 \%$, and $p$ is a dimensionless shape parameter (about 3 for many crops). Several studies found Eq. (2) to describe crop salt tolerance data equally well or better than Eq. (1) (Steppuhn et al., 2005; van Genuchten and Gupta, 1993). Dirksen et al. (1993) later included a threshold salinity in Eq. (2) to enable a more flexible description of salinity response data at low salinities:

$\alpha(E C)=\left\{\begin{array}{cc}1 & 0 \leq E C<E C^{*} \\ \frac{1}{1+\left[\left(E C-E C^{*}\right) /\left(E C_{50}-E C^{*}\right)\right]^{p}} & E C \geq E C^{*}\end{array}\right.$

The above salinity response functions were fitted to the observed data by minimizing the sum of the squared errors (SSE) between measured $\left(O_{i}\right)$ and model-predicted $\left(p_{i}\right)$ values using unweighted leastsquares regression:

$S S E=\sum_{i=1}^{n}\left(P_{i}-O_{i}\right)^{2}$

where $n$ is number of data-points. Since the reduction functions have different numbers of fitting parameters, the Akaike information criterion $(A I C)$ was further used to compare the performance of the three models. Since the number of data-points $(n)$ in comparison to the number of fitting parameters $(q)$ was relatively small in our study ( $n$ exceeded $q$ by only four or five), we used the corrected AIC (Bolster and Hornberger, 2007; Razzaghi et al., 2016) as follows:

$A I C=n \quad \ln \left(\left(\frac{S S E}{n}\right)+2(q+1)+\frac{2(q+1)(q+2)}{n-q-2}\right)$

The salinity response or reduction function with the lowest value of AIC was assumed to be the most accurate. To test if the improved accuracy was statistically sound and justified the extra parameters, the probability $(P)$ was calculated using (Razzaghi et al., 2016):

$P=\frac{\exp (0.5 \Delta)}{1+\exp (0.5 \Delta)}$

in which $\Delta$ is the absolute difference between the AIC values of the two reduction functions being evaluated. $P$ values were used to ensure that the decrease in SSE, required to accept the more accurate reduction function, is reasonable (Bolster and Hornberger, 2007; Razzaghi et al., 2016). After verifying the reduction functions, and to compare the various seed pre-treatments, the selected function parameters were analyzed following a completely randomized design with three replicates.

\section{Results and discussion}

\subsection{Seed germination as influenced by salinity and seed pre-treatment}

Values of the germination percentage (GP) and the germination rate $(G R)$ as affected by salinity are shown in Figs. 2 and 3, respectively, for both the control and the most effective seed pre-treatment concentrations. Table 2 lists the optimized values of the linear reduction functions for the optimal pretreatment concentrations as well as those for the other concentrations. Notice that the optimal pretreatment values were the same for GP and GR, being $1.5 \mathrm{mM}$ for Spd, $75 \mathrm{mM}$ for Asc, $12 \mathrm{mM}$ 


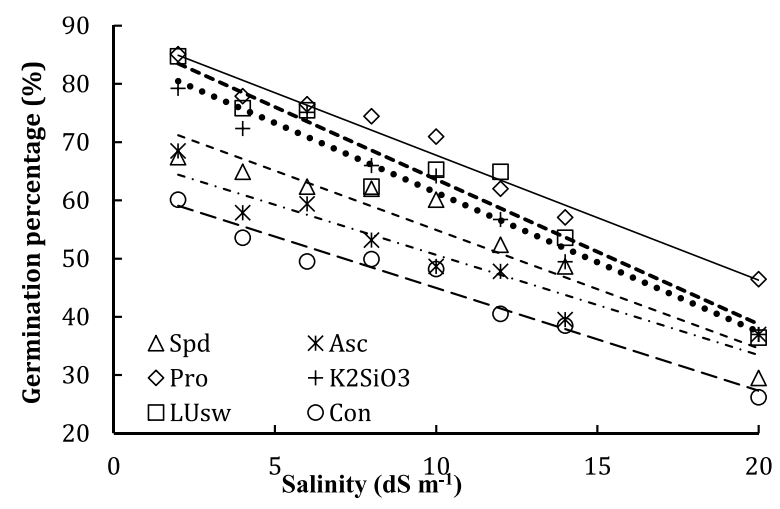

Fig. 2. Effect of salinity on germination percentage (GP) of Borage untreated or treated with the selected most effective seed pre-treatment concentrations (Spd, spermidine; Asc, ascorbic acid; Pro, proline; $\mathrm{K}_{2} \mathrm{SiO}_{3}$, potassium silicate; LUsw, Lake Urmia saline water; Con, control).

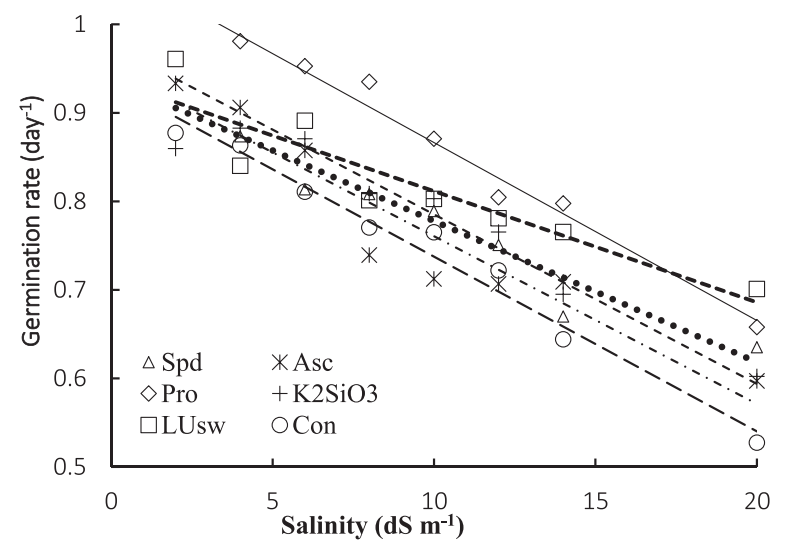

Fig. 3. Effect of salinity on the germination rate $(G R)$ of Borage untreated or treated with the selected most effective seed pre-treatment concentrations (Spd, spermidine; Asc, ascorbic acid; Pro, proline; $\mathrm{K}_{2} \mathrm{SiO}_{3}$, potassium silicate; LUsw, Lake Urmia saline water; Con, control).

for Pro, $1.5 \mathrm{mM}$ for $\mathrm{K}_{2} \mathrm{SiO}_{3}$, and $150 \mathrm{mg} \mathrm{L}^{-1}$ for LUsw. The data in Table 2 indicate a significant effect of seed pre-treatment concentration on the germination salinity reduction parameters. As reflected by the slope and y-intercept, Asc pretreatment at a concentration of $75 \mathrm{mM}$ was most effective in reducing the effects of salinity on both $G P$ and $G R$. The Pro data showed that although the $12 \mathrm{mM}$ concentration produced a more negative slope than the control, the y-intercept was higher than that for control. $\mathrm{K}_{2} \mathrm{SiO}_{3}$ seed pre-treatment at a concentration of $1.5 \mathrm{mM}$ had the most positive effect on increasing the y-intercept of GP (by $35 \%$ as compared to the control). The highest y-intercept for $G R$ was recorded for the control and $\mathrm{K}_{2} \mathrm{SiO}_{3}$ at a concentration of $1.5 \mathrm{mM} . \mathrm{K}_{2} \mathrm{SiO}_{3}$ at a concentration of 1.5 and $2 \mathrm{mM}$ reduced the slope of $G R$ by $20 \%$ as compared to the control. An Spd concentration of $1.5 \mathrm{mM}$ increased the y-intercept of GP and GR more than the other concentrations. This pretreatment concentration produced a milder slope of $G R$ as compared to the control and the other SPd concentrations. The most positive effect using LUsw was found with a concentration of $150 \mathrm{mM}$ as shown by the y-intercept of $G P$ and $G R$ and the slope of $G R$. Results for the control indicated that the negative influence of salinity was higher on GP than on $G R$, with a $56 \%$ decrease for $G P$ at $E C=20 \mathrm{dS} \mathrm{m}^{-1}$, compared to a $40 \%$ decrease for GR (see also Figs. 2 and 3).

The negative impact of salinity on germination may be due to the inhibiting effects of osmotic stress and/or a reduction in mobilization of seed food reserves at low salinity, except at higher salinities where ion toxicity may be the main reason for the negative response (Khajeh-Hosseini et al., 2003). Seed pre-treatments moderated the inhibitory
Table 2

Influence of the seed pretreatments on seed germination according to the parameters of regression lines.

\begin{tabular}{|c|c|c|c|c|c|}
\hline \multirow{2}{*}{$\begin{array}{l}\text { Seed pre- } \\
\text { treatment }\end{array}$} & \multirow[t]{2}{*}{ Concentration } & \multicolumn{2}{|l|}{$G P(\%)$} & \multicolumn{2}{|c|}{$G R$ (per day) } \\
\hline & & Slope & $\begin{array}{l}y- \\
\text { intercept }\end{array}$ & Slope & $\begin{array}{l}y- \\
\text { intercept }\end{array}$ \\
\hline \multirow[t]{4}{*}{ Asc (mM) } & 0 & $-1.76 a b$ & $62.61 c$ & $-0.020 \mathrm{ab}$ & $0.94 a$ \\
\hline & 50 & $-1.88 b c$ & $61.70 \mathrm{c}$ & $-0.021 a b$ & $0.79 c$ \\
\hline & 75 & $-1.72 \mathrm{a}$ & $67.85 \mathrm{a}$ & $-0.019 a$ & $0.95 a$ \\
\hline & 100 & $-1.92 \mathrm{c}$ & $64.28 \mathrm{~b}$ & $-0.022 b$ & $0.84 b$ \\
\hline \multirow[t]{4}{*}{ Pro (mM) } & 0 & $-1.76 a$ & $62.61 c$ & $-0.020 \mathrm{a}$ & $0.94 c$ \\
\hline & 12 & $-2.15 b$ & $89.22 \mathrm{a}$ & $-0.020 a$ & $1.07 \mathrm{a}$ \\
\hline & 17 & $-2.94 c$ & $84.03 \mathrm{~b}$ & $-0.023 b$ & $0.88 \mathrm{~d}$ \\
\hline & 25 & $-2.82 c$ & $85.06 \mathrm{~b}$ & $-0.023 b$ & $0.98 \mathrm{~b}$ \\
\hline \multirow{4}{*}{$\mathrm{K}_{2} \mathrm{SiO}_{3}(\mathrm{mM})$} & 0 & $-1.76 a$ & $62.61 d$ & $-0.020 b$ & $0.94 a$ \\
\hline & 1 & $-2.50 c$ & $78.01 \mathrm{c}$ & $-0.019 b$ & $0.91 b$ \\
\hline & 1.5 & $-2.39 b$ & $85.19 a$ & $-0.016 a$ & $0.95 a$ \\
\hline & 2 & $-2.51 c$ & $81.93 b$ & $-0.016 a$ & $0.87 \mathrm{c}$ \\
\hline \multirow[t]{4}{*}{ Spd (mM) } & 0 & $-1.76 a$ & $62.61 d$ & $-0.020 \mathrm{ab}$ & $0.94 b$ \\
\hline & 0.5 & $-2.23 c$ & $69.05 b$ & $-0.021 \mathrm{ab}$ & $0.90 c$ \\
\hline & 1 & $-2.12 b$ & $67.45 c$ & $-0.021 c$ & $0.91 c$ \\
\hline & 1.5 & $-2.03 b$ & $75.33 a$ & $-0.019 a$ & $0.98 \mathrm{a}$ \\
\hline \multirow{4}{*}{$\begin{array}{l}\text { LUsw } \\
\qquad\left(\mathrm{mg} \mathrm{L}^{-1}\right)\end{array}$} & 0 & $-1.76 a$ & $62.61 c$ & $-0.020 \mathrm{ab}$ & $0.94 \mathrm{ab}$ \\
\hline & 50 & $-2.58 b$ & $79.51 b$ & $-0.022 b$ & $0.92 b$ \\
\hline & 100 & $-2.58 b$ & $78.49 b$ & $-0.021 b$ & $0.91 \mathrm{~b}$ \\
\hline & 150 & $-2.54 b$ & $85.75 a$ & $-0.018 a$ & $0.94 \mathrm{a}$ \\
\hline
\end{tabular}

All GP and GR data are means. Values for each pretreatment compound followed by the same letter(s) are not significantly different according to Tukey's test $(P<0.05)$. Asc, ascorbic acid; Pro, proline; K2SiO3, potassium silicate; Spd, spermidine; LUsw, Lake Urmia saline water; GP, final germination percentage; GR, germination rate.

impacts of salinity stress on both GP and $G R$, as depicted by the upward shift of the curves in Figs. 2 and 3. During seed pre-treatment, the activity of XTH (xyloglucan endotrans hydrolase) improves to lead to an increase in the production of endo- $\beta$-mannanase, while simultaneously facilitating causing some cytoskeleton reorganization which is necessary for cell wall loosening. These modifications have been shown to accelerate the germination process (e.g., Lutts et al., 2016). Kazemi and Eskandari (2012) concluded that although seed pre-treatment presumably ameliorates seedling growth under saline conditions, seed and seedling performance seem to be affected by pre-treatment in a concentration-dependent manner. Moreover, the effects of concentration may depend on the type of pre-treatment.

The results in Table 2 show that the most effective concentrations of Spd, Asc, Pro, $\mathrm{K}_{2} \mathrm{SiO}_{3}$ and LUsw improved the $\mathrm{GR}$ by $2 \%, 4 \%, 5 \%, 11 \%$ and $13 \%$, respectively. The GP improved by $10 \%, 11 \%$ and $3 \%$ at the most effective concentration of Asc, Pro and $\mathrm{K}_{2} \mathrm{SiO}_{3}$, respectively, while the incremental effects of Spd and LUsw on GP were less than $1 \%$. GR hence was affected more by seed pre-treatment than GP. Results by Hamama and Murniati (2010) showed that of various concentrations of Asc $(0,55,110,165,220$, and $275 \mathrm{mM}), 55 \mathrm{mM}$ Asc produced the best results for $G P$, speed of germination, VI, length of the shoots, primary and seminal roots, and the number of seminal roots of maize. However, Hua-long et al. (2014) reported that increasing proline concentration as a seed pre-treatment (in the range of 5-45 $\mathrm{mM}$ ) improved GR and the relative germination energy $(R G E)$ of rice during salinity stress. Our results are very similar to previous studies. For example, positive effects of seed pre-treatment with silicon (Feghhenabi et al., 2020; Shi et al., 2014; Soukup et al., 2017; Torabi et al., 2012), polyamines (Farooq et al., 2008), Spd (Paul et al., 2017), Asc (Sabaghnia et al., 2016) and Pro (Taie et al., 2013) have been reported for seed germination, plant growth and/or plant salt tolerance.

\subsection{Seedling emergence as influenced by salinity and seed pre-treatment}

Salinity had a negative effect on the growth and development of the 
seedlings during the Phase- 2 experiments. Fig. 4 shows results for the four most important traits we investigated. We note that all plots in Fig. 4 are relative to the values of the control (i.e., no seed pre-treatment, and without any subsequent salinity stress). Each value hence reveals the combined effects of salinity and seed pre-treatment.

The response of seedlings to salinity was different for all salinity levels. In actuality, most traits responded in a similar fashion to increased salinity (Fig. 4). They showed a negligible decrease up to some salinity threshold, after which salinity had a much more significant effect. For example, $E_{\max }, R_{50}$ and $R E U$ of the control declined to about $95 \%, 65 \%$ and $55 \%$, respectively, at $E C=14 \mathrm{dS} \mathrm{m}^{-1}$. Among the seedling properties, root dry weight proved to be the most sensitive to salinity, showing reductions of $93 \%$ at a salinity of $14 \mathrm{dS} \mathrm{m}^{-1}$ (Fig. 4 and Table 3).

While most seed pre-treatments reduced the negative effects of salinity (Fig. 4), some pre-treatments produced lower amounts of the traits at relatively mild salinities (notably Asc for relative stem dry weight at salinities less than $6 \mathrm{dS} \mathrm{m}^{-1}$; see Fig. 4d). Seed pre-treatments had positive effects in two ways: $i$ ) by inhibiting the rate of salinityinduced reductions of the traits (e.g. of $E_{\max }$ for all pre-treatments except $\mathrm{K}_{2} \mathrm{SiO}_{3}$ and seedling stem dry weight), and ii) by delaying the initial decline of the measured traits (e.g. of $R_{50}$, seedling root dry weights). For some of the traits, several seed pre-treatments had a positive effect in terms of both aspects (e.g. for VI derived from Pro). In this regard, Chomontowski et al. (2020) also concluded that the main effects of seed pre-treatment were enhancement of seed viability, acceleration of germination, and seedling emergence. Overall, the general patterns of the traits in terms of their response to salinity were not changed by seed pre-treatment. For all seed pre-treatments, the traits decreased only marginally at relatively low salinities, whereas the rate of decrease and the threshold $E C$ values from which the trait started to decrease were not the same among the seed pre-treatments. These effects are assessed and quantified next in terms of the modeling approach.

The three salinity response functions given by Eqs. (1), (2) and (3) were used to describe changes in the traits in response to salinity under the influence of the seed pre-treatments. As an example, Fig. 5a shows the overall fit of the functions to the VI vs. salinity data for the control and the Spd treatments. In general, the van Genuchten and Hoffman (1984) response function had the lowest AIC values, followed by the Maas and Hoffman (1977) function (Fig. 5b). While those two functions statistically did not show significant differences in terms of their AIC values, they performed significantly better than the Dirksen et al. (1993) function (Figs. 5b and 6). Based on this finding, we focus further only on the van Genuchten and Hoffman (i.e., $E C_{50}$ ) and Maas and Hoffman $\left(E C^{*}\right.$ and $b$ ) parameters (Table 3 ). Averages of their functional parameters are listed in Table 3 (to be discussed in detail next).

\subsection{Quantitative representation of the effects of seed pre-treatment on plant response to salinity}

Generally, by raising salinity levels, values of the various seed emergence characteristics all decreased for both the control and all pretreatments. This reflects the fact that salinity slows down the overall growth process. Although growth reduction in most plants is a common effect of salinity stress (Skaggs et al., 2006; Chen and Arora, 2011), the actual biochemical and physiological processes responsible for the reductions are still not well understood (Munns and Tester, 2008; Noreen et al., 2010). Our study confirmed that pre-treatment of the seeds alleviated the adverse effects of salinity. Parameters of selected Maas and Hoffman (1977) and van Genuchten and Hoffman (1984) salinity response functions as given in Table 3 are now used to compare the effects of seed pre-treatment on various indices of the emergence of Borage seedlings.

The maximum emergence percentage $\left(E_{\max }\right)$ of the control started to decrease at $E C=5.5 \mathrm{dS} \mathrm{m}^{-1}\left(E C^{*}\right)$, with the decline reaching $50 \%$ $\left(E C_{50}\right)$ at $E C=10.5 \mathrm{dS} \mathrm{m}^{-1} . E C^{*}$ values for $E_{\max }$ as affected by Asc, Pro,
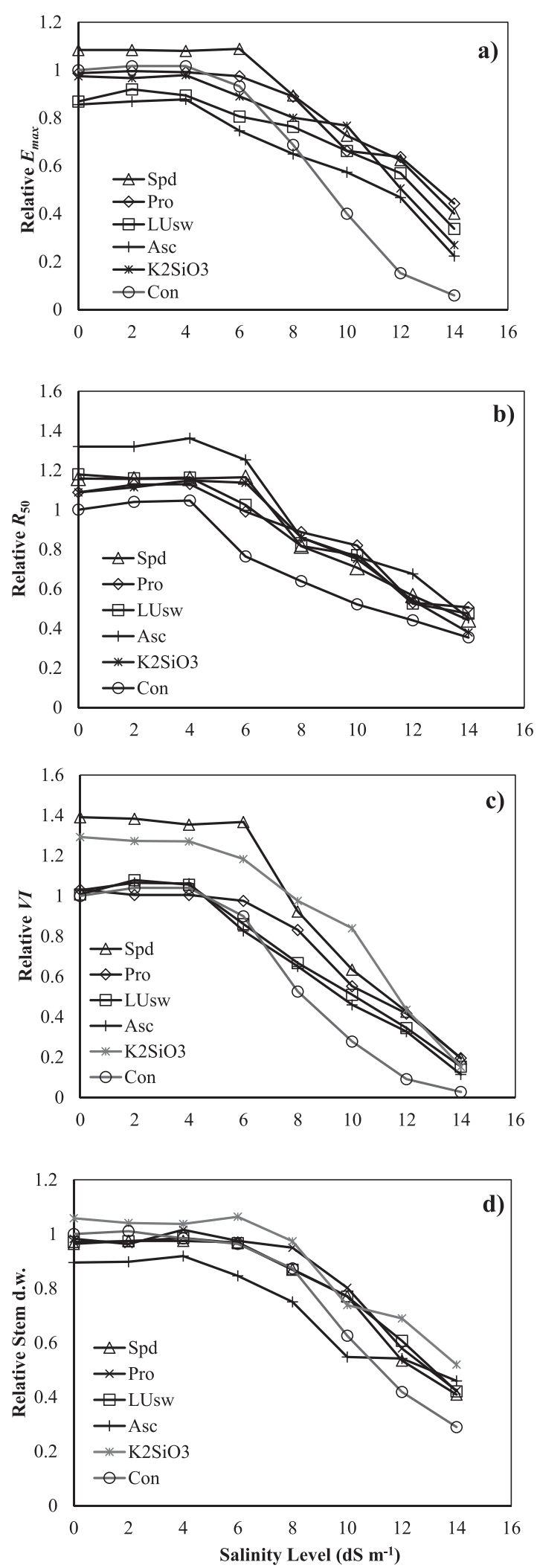

Fig. 4. Effect of salinity on relative values of $E_{\max }$ (a), $R_{50}$ (b), VI (c) and stem dry weight (d) of Borage untreated or treated with the selected most effective seed pre-treatment concentrations (Spd, spermidine; Asc, ascorbic acid; Pro, proline; $\mathrm{K}_{2} \mathrm{SiO}_{3}$, potassium silicate; LUsw, Lake Urmia saline water; Con, Control). 
Table 3

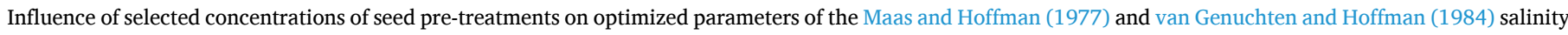
response functions used in this study for seedling and emergence attributes.

\begin{tabular}{|c|c|c|c|c|c|c|c|}
\hline \multirow[t]{2}{*}{ Trait } & \multirow[t]{2}{*}{ Parameter } & \multicolumn{6}{|c|}{ Seed pre-treatment } \\
\hline & & Control & Asc & Pro & $\mathrm{K}_{2} \mathrm{SiO}_{3}$ & Spd & LUsw \\
\hline \multirow[t]{3}{*}{$E_{\max }(\%)$ (final maximum emergence rate) } & $E C^{*}$ & $5.5 \mathrm{ab}$ & $4.6 \mathrm{~b}$ & $6.9 \mathrm{ab}$ & 7.9a & $6.3 \mathrm{ab}$ & $6.0 \mathrm{ab}$ \\
\hline & $b$ & $0.101 \mathrm{a}$ & $0.077 \mathrm{a}$ & $0.084 a$ & $0.113 \mathrm{a}$ & $0.078 \mathrm{a}$ & $0.067 \mathrm{a}$ \\
\hline & $E C_{50}$ & $10.5 \mathrm{a}$ & $10.8 \mathrm{a}$ & $12.9 \mathrm{a}$ & $12.3 \mathrm{a}$ & $12.5 \mathrm{a}$ & $12.5 \mathrm{a}$ \\
\hline \multirow[t]{3}{*}{$R_{50}$ (per day) (rate at which seedlings reached $50 \%$ ) } & $E C^{*}$ & $2.9 \mathrm{c}$ & $4.0 \mathrm{bc}$ & $4.3 \mathrm{~b}$ & $5.8 \mathrm{a}$ & $5.1 \mathrm{ab}$ & $3.8 \mathrm{bc}$ \\
\hline & $b$ & $0.065 b$ & $0.089 \mathrm{a}$ & $0.066 \mathrm{~b}$ & $0.092 \mathrm{a}$ & $0.085 \mathrm{ab}$ & $0.071 \mathrm{ab}$ \\
\hline & $E C_{50}$ & $10.1 \mathrm{c}$ & $11.1 \mathrm{bc}$ & $12.7 \mathrm{a}$ & $11.7 \mathrm{ab}$ & $11.6 \mathrm{~b}$ & $11.7 \mathrm{ab}$ \\
\hline \multirow[t]{3}{*}{$R E U$ (per day) (reciprocal of emergence uniformity) } & $E C^{*}$ & $3.8 \mathrm{a}$ & $0.4 \mathrm{~b}$ & $0.0 \mathrm{~b}$ & $3.0 \mathrm{a}$ & $3.3 \mathrm{a}$ & $0.0 \mathrm{~b}$ \\
\hline & $b$ & $0.063 \mathrm{ab}$ & $0.066 \mathrm{a}$ & $0.048 b$ & $0.069 \mathrm{a}$ & $0.050 \mathrm{~b}$ & $0.064 \mathrm{ab}$ \\
\hline & $E C_{50}$ & $11.6 \mathrm{ab}$ & $8.1 \mathrm{~d}$ & $10.1 \mathrm{bcd}$ & $11.1 \mathrm{abc}$ & $12.8 \mathrm{a}$ & $8.7 \mathrm{~cd}$ \\
\hline \multirow[t]{3}{*}{$V I$ (vitality index) } & $E C^{*}$ & $4.0 \mathrm{~b}$ & $3.7 \mathrm{~b}$ & $5.8 \mathrm{a}$ & $5.7 \mathrm{a}$ & $5.3 a$ & $4.0 \mathrm{~b}$ \\
\hline & $b$ & $0.110 \mathrm{~b}$ & $0.091 b c$ & $0.101 b c$ & $0.130 \mathrm{a}$ & $0.143 a$ & $0.089 c$ \\
\hline & $E C_{50}$ & $8.2 c$ & $9.1 \mathrm{~b}$ & $10.7 \mathrm{a}$ & $10.7 \mathrm{a}$ & $9.7 \mathrm{~b}$ & $9.5 \mathrm{~b}$ \\
\hline \multirow{3}{*}{ Root length (cm) } & $E C^{*}$ & $3.5 c$ & $6.5 \mathrm{a}$ & $5.1 \mathrm{~b}$ & $7.6 \mathrm{a}$ & $3.7 \mathrm{c}$ & $3.9 c$ \\
\hline & $b$ & $0.044 c$ & $0.074 b$ & $0.047 \mathrm{c}$ & $0.114 a$ & $0.067 b$ & $0.069 b$ \\
\hline & $E C_{50}$ & $14.3 \mathrm{a}$ & $13.5 \mathrm{a}$ & $14.3 \mathrm{a}$ & 13.2ab & $11.9 \mathrm{~b}$ & $11.5 \mathrm{~b}$ \\
\hline \multirow[t]{3}{*}{ Stem length. (cm) } & $E C^{*}$ & $4.2 \mathrm{bc}$ & $2.3 \mathrm{~d}$ & $6.5 \mathrm{a}$ & $5.0 \mathrm{~b}$ & $4.9 \mathrm{~b}$ & $3.7 \mathrm{c}$ \\
\hline & $B$ & $0.056 \mathrm{~b}$ & $0.066 \mathrm{ab}$ & $0.071 \mathrm{a}$ & $0.056 \mathrm{~b}$ & $0.067 \mathrm{a}$ & $0.056 \mathrm{~b}$ \\
\hline & $E C_{50}$ & $12.2 \mathrm{c}$ & $10.8 \mathrm{~d}$ & $13.6 \mathrm{ab}$ & $14.4 \mathrm{a}$ & $13.5 \mathrm{ab}$ & $12.9 b c$ \\
\hline \multirow[t]{3}{*}{ Root dry weight (g) } & $E C^{*}$ & $1.5 \mathrm{c}$ & $3.9 \mathrm{~b}$ & $4.5 \mathrm{~b}$ & $7.2 \mathrm{a}$ & $4.3 \mathrm{~b}$ & $1.7 \mathrm{c}$ \\
\hline & $b$ & $0.061 \mathrm{c}$ & $0.082 b$ & $0.063 c$ & $0.133 \mathrm{a}$ & $0.125 a$ & $0.089 \mathrm{~b}$ \\
\hline & $E C_{50}$ & $8.2 \mathrm{c}$ & $10.7 \mathrm{~b}$ & $12.0 \mathrm{a}$ & $12.4 \mathrm{a}$ & $10.9 \mathrm{~b}$ & $7.9 c$ \\
\hline \multirow[t]{3}{*}{ Stem dry weight (g) } & $E C^{*}$ & $4.4 \mathrm{bc}$ & $3.6 \mathrm{c}$ & $6.1 \mathrm{a}$ & $5.6 \mathrm{ab}$ & $5.1 \mathrm{ab}$ & $5.9 a$ \\
\hline & $b$ & $0.061 \mathrm{a}$ & $0.038 \mathrm{c}$ & $0.057 \mathrm{ab}$ & $0.053 \mathrm{ab}$ & $0.050 \mathrm{~b}$ & $0.060 \mathrm{a}$ \\
\hline & $E C_{50}$ & $11.4 \mathrm{~b}$ & $14.1 \mathrm{a}$ & $13.6 \mathrm{a}$ & $14.4 \mathrm{a}$ & $13.7 \mathrm{a}$ & $13.3 \mathrm{a}$ \\
\hline
\end{tabular}

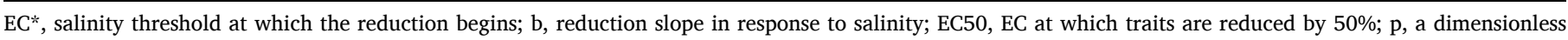

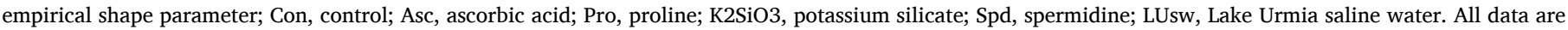
means. Values for each pretreatment compound followed by the same letter(s) are not significantly different according to Tukey's test $(P<0.05)$.
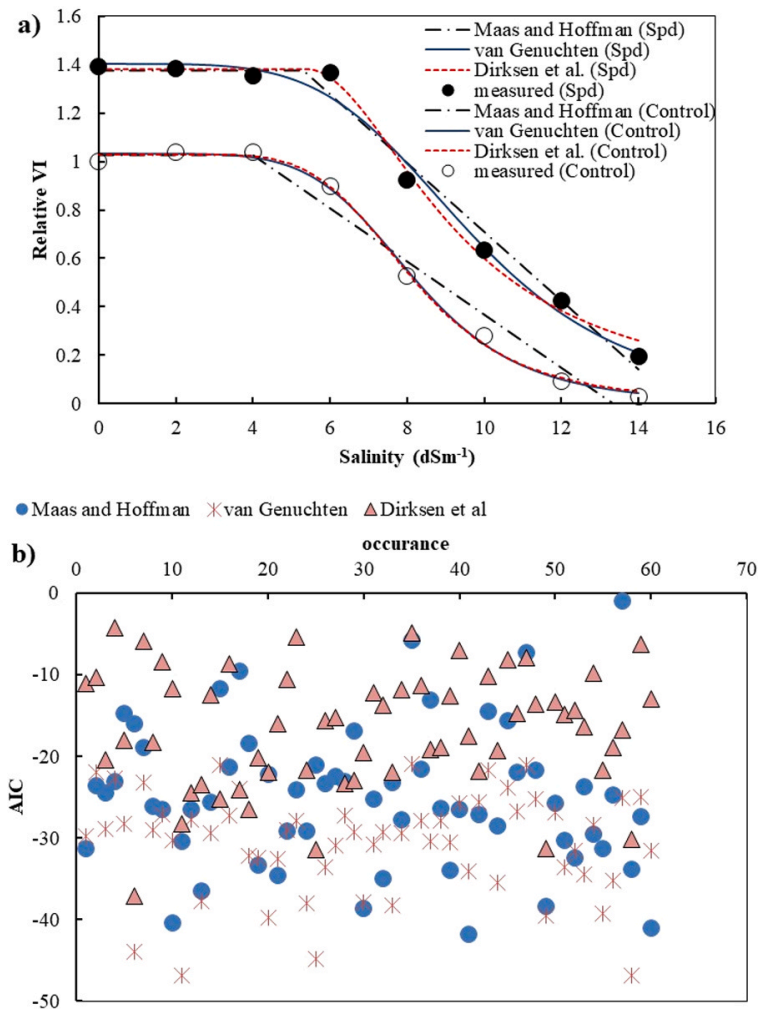

Fig. 5. Overall fit of the applied reduction functions to the experimental data for the vitality index $(V I)$ versus salinity for the control and the spermidine (Spd) treated seeds (top), and comparison of the Akaike information criterion (AIC) among the reduction functions used (bottom).

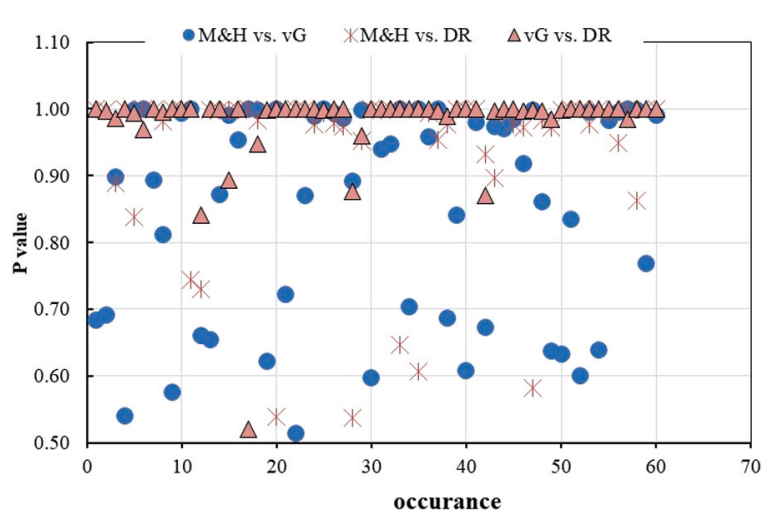

Fig. 6. $P$ values calculated to test at what probability level the salinity response function with the lowest $A I C$ is the most accurate function (M\&H: Maas and Hoffman; DR: Dirksen et al.; vG: van Genuchten and Hoffman).

$\mathrm{K}_{2} \mathrm{SiO}_{3}$, Spd and LUsw were 4.6, 6.9, 7.9, 6.3 and $6.0 \mathrm{dS} \mathrm{m}{ }^{-1}$, respectively. $E C_{50}$ and $b$ were not affected significantly by seed pre-treatments (Table 3). Results by Carrillo-Reche et al. (2018) showed that seed pre-treatment has a significantly positive effect on seedling performance with an increased final emergence of $11 \%$. Cell cycle pre-activation of cell cycle is a likely reason for the better performance of pre-treated seeds over un-treated seeds (Lutts et al., 2016).

Higher values of the $50 \%$ emergence rate $\left(R_{50}\right)$ is the primary factor that ensures overall seedling performance. Islam et al. (2015) elaborated that emergence rate is one of the crucial contributors of seed vigor under salinity stress. The highest $E C^{*}$ value for $R_{50}$ was obtained for $\mathrm{K}_{2} \mathrm{SiO}_{3}$-treated seedlings $\left(E C^{*}=5.8 \mathrm{dS} \mathrm{m}^{-1}\right.$ ), and the lowest value for the control seedlings $\left(E C^{*}=2.9 \mathrm{dS} \mathrm{m}^{-1}\right)$. Seed pre-treatment hence decreased the sensitivity of the seedlings to salinity by increasing $E C^{*}$ for $R_{50} . R_{50}$ of the control seedlings decreased to $50 \%\left(E C_{50}\right)$ at $E C$ $=10.1 \mathrm{dS} \mathrm{m}^{-1}$, while $E C_{50}$ values for Asc, Pro, $\mathrm{K}_{2} \mathrm{SiO}_{3}$, Spd and LUsw were more than $E C_{50}$ of the control (Table 3). Nonetheless, $b$ for $R_{50}$ was 
the highest for the Asc and $\mathrm{K}_{2} \mathrm{SiO}_{3}$ pre-treatments. Seed pre-treatment increased the average $E C^{*}$ and $E C_{50}$ values of $R_{50}$ by $54 \%$ and $16 \%$, respectively. This shows that seed pre-treatment was more effective at low salinities than at high salinities. Any factor that affects the emergence rate also has the potential to change yield. By increasing the emergence rate, the possibility of using growth factors increases and more yield is achieved. Therefore, seed pre-treatment has the potential to increase yield under saline conditions by accelerating and synchronizing germination and seed emergence, and subsequently enhancing plant growth, improving stress resistance, and increasing the use efficiency of nutrients and water (Lutts et al., 2016).

The uniformity of seedling emergence $(E U)$ is an important characteristic for field management. Nonuniformity in seedling emergence has been shown to decrease yields. $E U$ is the time from $10 \%$ to $90 \%$ of final emergence (Liu et al., 2017). Reciprocal values of the emergence uniformity $(R E U)$ were fitted to the reduction functions of the seed pre-treatment scenarios; they indicated that $E C^{*}$ was reduced by Asc, Pro and LUsw, while $E C^{*}$ for $\mathrm{K}_{2} \mathrm{SiO}_{3}$ and Spd was statistically on par with the control. However, the $R E U$ obtained for Spd had $E C_{50}$ values higher than those of the control, while the other seed pre-treatments had mostly lower $E C_{50}$ values. On the other hand, the slope $b$ of $R E U$ decreased for the Spd and Pro seed pre-treatments, but increased or remained the same for the other pre-treatments compared to the control. The positive effect of seed pre-treatments on $E C^{*}$ of $E_{\max }$ and $R_{50}$ was not observed on $E C^{*}$ of the reciprocal of the emergence uniformity $(R E U)$. The positive effect of seed pre-treatments on $E C^{*}$ of $E_{\max }$ and $R_{50}$ and the lower $E C^{*}$ for $R E U$ by some seed pre-treatments showed that seed pre-treatment is more effective in reducing the time required for $50 \%$ seedling emergence, than improving $90 \%$ seedling emergence.

The vitality index $(V I)$ is a composite indicator accounting for three attributes (root length, stem length and $E_{\max }$ ). Being one of the primary determinants of high yield, VI is directly and negatively affected by salinity (Rajabi Dehnavi et al., 2020). The vitality index is one of the most essential indicators of improved crop management, particularly of optimal crop establishment and increasing the plant's ability to tolerate different stress (He et al., 2019). The Pro, $\mathrm{K}_{2} \mathrm{SiO}_{3}$ and Spd pre-treatments were found to delay the decline of $V I\left(E C^{*}\right)$ to higher salinities. Asc and LUsw had no significant effect on $E C^{*}$. However, $\mathrm{K}_{2} \mathrm{SiO}_{3}$ along with Spd increased the slope $b$ of VI, while Asc, Pro and LUsw decreased the value of $b$. All seed pre-treatments had a positive effect only on $E C_{50}$ of VI, with $\mathrm{K}_{2} \mathrm{SiO}_{3}$ and Pro (both $31 \%$ higher than the control) being the most effective. Sarika et al. (2013) reported that seed pre-treatment improved the seed quality and showed improved seedling length and seedling dry weight, which in turn improved higher seedling vigor, germination rates and mean germination times.

The highest root length $E C^{*}$ was obtained with the Asc, Pro and $\mathrm{K}_{2} \mathrm{SiO}_{3}$ pre-treatments (which were $84 \%, 46 \%$ and $116 \%$ higher than the control, respectively). However, $E C_{50}$ did not change significantly with the Asc, Pro and $\mathrm{K}_{2} \mathrm{SiO}_{3}$ seed pre-treatments because of a simultaneous increase in the reduction slopes, $b$ 's. $E C^{*}$ and $E C_{50}$ of stem length for the control were 4.2 and $12.2 \mathrm{dS} \mathrm{m}^{-1}$, respectively. A possible reason for the reductions in stem and root length is decreased turgor pressure at higher salinities, which reduces cell enlargement and shortens shoots (Izzo et al., 1991). Reductions in stem length were delayed by the Pro, $\mathrm{K}_{2} \mathrm{SiO}_{3}$ and Spd pre-treatments relative to the control. Furthermore, the stem length average $E C_{50}$ values of the pre-treatments (except Asc) were about $11 \%$ higher than the control. The highest $E C^{*}$ and $E C_{50}$ values were obtained with Pro and $\mathrm{K}_{2} \mathrm{SiO}_{3}$, respectively. However, $\mathrm{K}_{2} \mathrm{SiO}_{3}$ along with LUsw had no significant effect on $b$ of stem length. The other seed pre-treatments increased $b$.

Of all measured traits, root dry weight had the highest susceptibility to salinity (according to $E C^{*}$ for the control). However, all seed pretreatments (except LUsw) were able to improve $E C^{*}$ and $E C_{50}$ of root dry weight. The highest $E C^{*}$ value was obtained with $\mathrm{K}_{2} \mathrm{SiO}_{3}$. Moreover, $\mathrm{K}_{2} \mathrm{SiO}_{3}$ along with Pro had the highest $E C_{50}$. The increasing effect of all seed pre-treatments (except Pro) was observed on $b$. Indeed, all seed pre- treatments except Pro had a negative effect on $b . E C^{*}$ and $E C_{50}$ values of stem dry weight for the control were 4.4 and $11.4 \mathrm{dS} \mathrm{m}^{-1}$, respectively. Seed pre-treatments increased the $E C^{*}$ and $E C_{50}$ values of stem dry weight (except $E C^{*}$ for Asc). The highest $E C^{*}$ values of stem dry weight were for Pro. The effect of all seed pre-treatments on $E C_{50}$ was statistically similar and higher than the control. Moreover, all seed pretreatments except LUsw decreased $b$ of stem dry weight. Among these, Asc was the most effective seed pre-treatment with a $37 \%$ reduction.

When averaged over all traits, seed pre-treatment increased the mean salinity threshold, $E C^{*}$. The most effective pre-treatment was $\mathrm{K}_{2} \mathrm{SiO}_{3}$, which increased the mean $E C^{*}$ values to $5.9 \mathrm{dS} \mathrm{m}^{-1}(60 \%)$, compared to $3.7 \mathrm{dS} \mathrm{m}^{-1}$ for the control (Table 3). The effect of Spd and Pro on the $E C^{*}$ was less than that of $\mathrm{K}_{2} \mathrm{SiO}_{3}$. The mean $E C$ value at which various traits were reduced by $50 \%$ (i.e., $E C_{50}$ ) increased from $10.8 \mathrm{dS} \mathrm{m}^{-1}$ for the control to $11.2,12.5,12.5,12.1$ and $11.2 \mathrm{dS} \mathrm{m}^{-1}$ for the Asc, Pro, $\mathrm{K}_{2} \mathrm{SiO}_{3}$, Spd and LUsw pre-treatments, respectively. Statistically, the effects of Pro, $\mathrm{K}_{2} \mathrm{SiO}_{3}$, and Spd on $E C_{50}$ were the same. Moreover, $E C_{50}$ of Asc, and LUsw were at the same level as the control.

In general, the effects of seed pre-treatments on most traits were more positive on $E C^{*}$ and $E C_{50}$, as compared to $b$. According to Table 3, the most effective results in reducing the impacts of salinity were obtained with Pro, $\mathrm{K}_{2} \mathrm{SiO}_{3}$ and Spd. However, Fig. 3 indicates that most seed pre-treatments particularly $\mathrm{K}_{2} \mathrm{SiO}_{3}$ and Spd had a positive effect on enhancing seedling attributes, especially VI, at most salinity levels. Ultimately, also from an economical perspective, one may conclude that application of $\mathrm{K}_{2} \mathrm{SiO}_{3}$ is most effective of all seed pretreatments. Our results about the positive effects of seed pre-treatment are in line with findings by Anaya et al. (2015) for broad bean, Moghanibashi et al. (2015) for sunflower, Patanè et al. (2009) for sweet sorghum, and Feghhenabi et al. (2020) for wheat.

\section{Conclusions}

Our results show that seed pre-treatment alleviates the negative effects of salinity on seed germination and establishment of Borage (Borago officinalis L.) as evaluated in terms of indices such as germination percentage $(G P)$, germination rate $(G R)$, final maximum emergence $\left(E_{\max }\right)$, the vitality index $(V I)$ and seedling growth. Our analysis in terms of the salinity response functions provided quantitative insight about the type of results to be expected. Furthermore, the salinity response functions are potentially very useful for evaluating proposed or anticipated changes in operating conditions. According to the functional parameters (especially $E C^{*}$ and $E C_{50}$ ) and the relative values of the seedling attributes, seed pre-treatment with Pro, $\mathrm{K}_{2} \mathrm{SiO}_{3}$ and Spd induced the more positive changes in seedlings. Overall in terms of economics, application of $\mathrm{K}_{2} \mathrm{SiO}_{3}$ is the most appealing.

From a practical point of view, when saline water is available for irrigation at sowing, it may be useful to use pre-treated seeds. Moreover, reduction functions can help to predict the critical salinity threshold value and the rate of reduction at each salinity level. However, more studies are required to better understand relationships between different seed pre-treatment materials and salinity stress, and whether the positive effects of seed pre-treatments on early growth are also applicable during later growth stages. Similar analyses, also at the larger field scales and for different soil types, hence may be needed to obtain more definite conclusions.

\section{Declaration of Competing Interest}

The authors declare that they have no conflict of interest.

\section{References}

Ajmal Khan, M., Zaheer Ahmed, A., Hameed, A., 2006. Effect of sea salt and L-ascorbic acid on the seed germination of halophytes. J. Arid Environ. 67, 535-540. 
Aloui, H., Souguir, M., Latique, S., Hannachi, C., 2014. Germination and growth in control and primed seeds of pepper as affected by salt stress. Cercet. Agron. în Mold. 3, 83-95.

Anaya, F., Fghire, R., Wahbi, S., Loutfi, K., 2015. Influence of salicylic acid on seed germination of Vicia faba L. under salt stress. J. Saudi Soc. Agric. 0-7.

Asadi-Samani, M., Bahmani, M., Rafieian-Kopaei, M., 2014. Chemical composition, botanical characteristic and biological activities of Borago Officinalis: a review. Asian Pac. J. Trop. Med. 7, S22-S28.

KhoshKholg Sima, N.A., Alitabar, R., Eqbalinejad, M., Babazade, P., Taleahmad, S., 2014. Effect of salinity on barley germination and tolerance threshold. Iran. J. Field Crop Res. 11, 107-120.

Babakhanzade Sajirani, E., Shakouri, M.J., Mafakheri, S., 2011. Borage (Borago officinalis L.) germination under saline condition. Ann. Biol. Res. 2, 414-416.

Bagheri, R., Bashiri, H., Ahmad, J., Iqbal, M., Qureshi, M.I., 2015. Spinach (Spinacia oleracea L.) modulates its proteome differentially in response to salinity, cadmium and their combination stress. Plant Physiol. Biochem. 97, 235-245.

Bojovi, B., Đelić, G., Topuzovi, M., Stanković, M., 2010. Effects of $\mathrm{NaCl}$ on seed germination in some species from families Brassicaceae and Solanaceae. Kragujev. J. Sci. 32, 83-87.

Bolster, C.H., Hornberger, G.M., 2007. On the use of linearized Langmuir equations. Soil Sci. Soc. Am. J. 71 (6), 1796-1806.

Carrillo-Reche, J., Vallejo-Marín, M., Quilliam, R.S., 2018. Quantifying the potential of 'on-farm' seed priming to increase crop performance in developing countries. A meta-analysis. Agron. Sustain. Dev. 38, 64.

Chakovari, S.Z., Enteshari, S., Qasimov, N., 2016. Effect of salinity stress on biochemical parameters and growth of borage (Borago officinalis L.). Iran. J. Plant Physiol. 6, 1673-1685.

Chen, K., Arora, R., 2011. Dynamics of the antioxidant system during seed osmopriming, post-priming germination and seedling establishment in spinach (Spinacia oleracea). Plant Sci. 180, 212-220.

Chomontowski, C., Wzorek, H., Podlaski, S., 2020. Impact of sugar beet seed priming on seed quality and performance under diversifed environmental conditions of germination, emergence and growth. J. Plant Growth Regul. 39, 183-189.

Demir Kaya, M., Okcu, G., Atak, M., Cilkli, Y., Kolsarici, O., 2006. Seed treatments to overcome salt and drought stress during germination in sunflower (Helianthus annuus L.). Eur. J. Agron. 24, 291-295.

Dirksen, C., Kool, J.B., Koorevaar, P., van Genuchten, M.Th, 1993. HYSWASORSimulation model of hysteretic water and solute transport in the root zone. Water Flow. Solute Transp. Soils 99-122.

Farooq, M., Basra, S.M.A., Hussain, M., 2008. Seed priming with polyamines improves the germination and early seedling growth in fine. J. New Seeds 9, 145-155.

Feghhenabi, F., Hadi, H., Khodaverdiloo, H., van Genuchten, M.Th, 2020. Seed priming alleviated salinity stress during germination and emergence of wheat (Triticum aestivum L.). Agric. Water Manag. 231, 106022.

Ghassemi-golezani, K., Dastborhan, S., Zehtab-salmasi, S., 2013. Seed priming and field performance of borage (Borago officinalis L.) under different irrigation treatments. IJAPP 4, 82-87.

Hamama, H., Murniati, E., 2010. The effect of ascorbic acid treatment on viability and vigor maize (Zea mays L.) seedling under drought stress. HAYATI J. Biosci. 17, 105-109.

He, X., Feng, X., Sun, D., Liu, F., Bao, Y., He, Y., 2019. Rapid and nondestructive measurement of rice seed vitality of different years using near-infrared hyperspectral imaging. Molecules 24 (2227), 1-14.

Hua-long, L., Han-jing, S., Jing-guo, W., Yang, L., De-tang, Z., Hong-wei, Z., 2014. Effect of seed soaking with exogenous proline on seed germination of rice under salt stress. J. Northeast Agric. Univ. 21, 1-6.

Ibrahim, E.A., 2016. Seed priming to alleviate salinity stress in germinating seeds. J. Plant Physiol. 192, 38-46.

Islam, F., Yasmeen, T., Ali, S., Ali, B., Farooq, M.A., Gill, R.A., 2015. Priming-induced antioxidative responses in two wheat cultivars under saline stress. Acta Physiol. Plant. 37, 153.

Izzo, R., Navari-Izzo, F., Quartacci, M.F., 1991. Growth and mineral absorption in maize seedlings as affected by increasing $\mathrm{NaCl}$ concentrations. J. Plant Nutr. 14, 687-699.

Kadkhodaie, A., Bagheri, M., 2012. Seed treatment to overcome salt and drought stresses during germination in linseed (Linum usitatissimum L.). J. Res. Agr. Sci. 8, 141-151.

Kafi, M., Rahimi, Z., 2011. Effect of salinity and silicon on root characteristics, growth, water status, proline content and ion accumulation of purslane (Portulaca oleracea L.). Soil Sci. Plant Nutr. 57, 341-347.

Kazemi, K., Eskandari, H., 2012. Does priming improve seed performance under salt and drought stress? J. Basic Appl. Sci. Res. 2, 3503-3507.

Khajeh-Hosseini, M., Powell, A.A., Bingham, I.J., 2003. The interaction between salinity stress and seed vigour during germination of soyabean seeds. Seed Sci. Technol. 31, $715-725$.

Kutlu, I., Ayter, N.G., Budak, Z., 2009. Genetic variations of triticale genotypes in different $\mathrm{NaCl}$ concentrations. JABS 3, 21-27.

Li, J.-Y., He, X.-W., Xu, L., Zhou, J., Wu, P., Shou, H.-X., Zhang, F.-C., 2008. Molecular and functional comparisons of the vacuolar $\mathrm{Na}^{+} / \mathrm{H}^{+}$exchangers originated from glycophytic and halophytic species. J. Zhejiang Univ. Sci. 9, 132-140.

Li, Z., Peng, Y., Zhang, X.-Q., Ma, X., Huang, L.-K., Yan, Y.-h, 2014. Exogenous spermidine improves seed germination of white clover under water stress via involvement in starch metabolism, antioxidant defenses and relevant gene expression. Molecules 19, 18003-18024.

Liu, T., Li, R., Jin, X., Ding, J., Zhu, X., Sun, C., Guo, W., 2017. Evaluation of seed emergence uniformity of mechanically sown wheat with UAV RGB imagery. Remote Sens. 9 (1241), 1-15.
Lutts, S., Benincasa, B., Wojtyla, L., Kubala, S.S., Pace, R., Lechowska, K., Quinet, M., Garnczarska, M., 2016. Seed priming: new comprehensive approaches for an old empirical technique. In: Araujo, S., Balestrazzi, A. (Eds.), New Challenges in Seed Biology-Basic and Translational Research Driving Seed Technology. Publish with Intech Open, pp. 1-46.

Maas, E.V., Hoffman, C.J., 1977. Crop salt tolerance-current assessment. J. Irrig. Drain. Div. 103, 110-134.

Maggio, A., Pascale, S.D., Angelino, G., Ruggiero, C., Barbieri, G., 2004. Physiological response of tomato to saline irrigation in long-term salinized soils. Eur. J. Agron. 21, 149-159.

Moghanibashi, M., Karimmojeni, H., Nikneshan, P., 2015. Seed treatment to overcome drought and salt stress during germination of sunflower (Helianthus annuus L.). J. Agrobiol. 30 (2), 89-96.

Mukhtar, A., Qadeera, U., Ahmeda, Z.I., Hassan, F., 2015. Improvement of wheat (Triticum aestivum) drought tolerance by seed priming with silicon. Arch. Agron. Soil Sci. $37-41$.

Munns, R., Tester, M., 2008. Mechanisms of salinity tolerance. Annu. Rev. Plant Biol. 59, 651-681.

Naghdi Badi, H., Sorooshzadeh, A., 2011. Evaluating potential of Borage (Borago officinalis L.) in bioremediation of saline soil. Afr. J. Biotechnol. 10, 146-153.

Noreen, Z., Ashraf, M., Akram, N.A., 2010. Salt-induced regulation of some key antioxidant enzymes and physio-biochemical phenomena in five diverse cultivars of turnip (Brassica rapa L.). J. Agron. Crop Sci. 196, 273-285.

Patade, V.Y., Bhargava, S., Suprasanna, P., 2009. Halopriming imparts tolerance to salt and PEG induced drought stress in sugarcane. Agric. Ecosyst. Environ. 134, 24-28.

Patanè, C., Cavallaro, V., Cosentino, S.L., 2009. Germination and radicle growth in unprimed and primed seeds of sweet sorghum as affected by reducedwater potential in $\mathrm{NaCl}$ at different temperatures. Ind. Crops Prod. 30, 1-8.

Paul, S., Roychoudhury, A., Banerjee, A., Chaudhuri, N., Ghosh, P., 2017. Seed pretreatment with spermidine alleviates oxidative damages to different extent in the salt $(\mathrm{NaCl})$-stressed seedlings of three indica rice cultivars with contrasting level of salt tolerance. Plant Gene 11, 112-123.

Pill, W.G., Frett, J.J., Morneau, D.C., 1991. Germination and seedling emergence of primed tomato and asparagus seeds under adverse conditions. HortScience 26, 1160-1162.

Rajabi Dehnavi, A., Zahedi, M., Ludwiczak, A., Cardenas Perez, S., Piernik, A., 2020. Effect of salinity on seed germination and seedling development of sorghum (Sorghum bicolor (L.) Moench) genotypes. Agronomy 10 (859), 1-15.

Razzaghi, S., Khodaverdiloo, H., Ghorbani Dashtaki, S., 2016. Effects of long-term wastewater irrigation on soil physical properties and performance of selected infiltration models in a semi-arid region. Hydrol. Sci. J. 61 (10), 1778-1790.

Saadat, S., Homaee, M., 2015. Modeling sorghum response to irrigation water salinity at early growth stage. Agric. Water Manag. 152, 119-124.

Sabaghnia, N., Yousefzadeh, S., Janmohammadi, M., Mohebodini, M., 2016. Pre-sowing seed treatments with silicon nano-iron and nano-silicon particles on germination of dragonhead. Plant Breed. Seed Sci. 74, 100-107.

Sadeghi, H., Robati, Z., 2015. Response of Cichorium intybus L. to eight seed priming methods under osmotic stress conditions. Biocatal. Agric. Biotechnol. 4, 443-448.

Sarika, G., Basavaraju, G.V., Bhanuprakash, K., Chaanakeshava, V., Paramesh, R., Radha, B.N., 2013. Investigation on seed viability and vigour of aged seed by priming in French bean. Veg. Sci. 40, 169-173.

Shafiq, F., Raza, S.H., Bibi, A., Khan, I., Iqbal, M., 2018. Influence of proline priming on antioxidative potential and ionic distribution and its relationship with salt tolerance of wheat. Cereal Res. Commun. 46 (2), 287-300.

Shakirova, F.M., Sakhabutdinova, A.S., Bezrukova, M.V., Fatkhutdinova, R.A. Fatkhutdinova, D.R., 2003. Changes in the hormonal status of wheat seedlings induced by salicylic acid and salinity. Plant Sci. 164, 317-322.

Shi, Y., Zhang, Y., Yao, H., Wu, J., Sun, H., Gong, H., 2014. Silicon improves seed germination and alleviates oxidative stress of bud seedlings in tomato under water deficit stress. Plant Physiol. Biochem. 78, 27-36.

Sivritepe, N., Sivritepe, H.O., Eris, A., 2003. The effect of $\mathrm{NaCl}$ priming on salt tolerance in melon seedlings. Sci. Hortic. 97, 229-237.

Skaggs, T.H., van Genuchten, M.Th, Shouse, P.J., Poss, J.A., 2006. Macroscopic approaches to root water uptake as a function of water and salinity stress. Agric. Water Manag. 86, 140-149.

Soukup, M., Martinka, M., Bosnic, D., Caplovicova, M., Elbaum, R., Lux, A., 2017. Formation of silica aggregates in sorghum root endodermis is predetermined by cell wall architecture and development. Ann. Bot. 120, 739-753.

Steppuhn, H., van Genuchten, M.Th, Grieve, C.M., 2005. Root-zone salinity: I. selecting a product - yield index and response function for crop tolerance. Crop Sci. 45, 209-220.

Taie, H.A.A., Abdelhamid, M.T., Dawood, M.G., Nassar, R.M.A., 2013. Pre-sowing seed treatment with proline improves some physiological, biochemical and anatomical attributes of faba bean plants under sea water. J. Appl. Sci. Res. 9, 2853-2867.

Torabi, F., Majd, A., Enteshari, S., 2012. Effect of exogenous silicon on germination and seedling establishment in Borago officinalis L. J. Med. Plant Res. 6, 1896-1901.

Uddin, M.K., Juraimi, A.S., 2013. Salinity tolerance turfgrass: history and prospects. Sci. World J. 2013, 1-6.

van Genuchten, M.Th, Gupta, S.K., 1993. A reassessment of the crop response function. J. Indian Soc. Soil Sci. 41, 730-737.

van Genuchten, M.Th, Hoffman, G.J., 1984. In: Shainberg, I. (Ed.), Analysis of Crop Production, in Soil Salinity Under Irrigation. Shalhevet J. Springer, New York, pp. 258-271.

Wei, L.-X., Lv, B.-S., Wang, M.-M., Ma, H.-Y., Yang, H.-Y., Liu, X.-L., Jiang, C.-J., Liang, Z. W., 2015. Priming effect of abscisic acid on alkaline stress olerance in rice (Oryza sativa L.) seedlings. Plant Physiol. Biochem. 90, 50-57. 